\title{
The view of foster parents' on the adequacy of foster care grant in meeting the needs of recipients in Amathole District, South Africa
}

\author{
Eleanor A. Hendricks ${ }^{1}$
}

\begin{abstract}
Initially, foster care grant were intended to assist children removed from their families of origin and placed in alternative care due to their vulnerability, neglect and abuse. Foster care grant forms part of the child protection system, and is issued to children who require care and protection and are deprived of proper upkeep. The aim of the study was to explore the view of foster parents on the sufficiency of the child support grant in meeting the basic needs of recipients. The study adopted a qualitative research approach. In-depth interviews were used to collect data with purposively selected participants. The finding of this study revealed that the grant is sufficient in providing for the nutritional, educational and sartorial needs of beneficiaries. The study sample consisted of 25 participants. The study concluded that the grant is sufficient but could be increased to provide funds for some additional needs such as savings policies, which is essential for securing a decent future for children.
\end{abstract}

Keywords: sufficiency; basic needs; foster care grant; beneficiaries; South Africa

1. University of Fort Hare, South Africa

Address for correspondence: ehendricks@ufh.ac.za

Date of first (online) publication 3rd April 2021 


\section{Introduction and background}

Aftert the apartheid era, the democratic government introduced multiple programmes to aid formally disadvantaged citizens deprived of many rights and denied access to resources in South Africa. Government came up with ways of reducing poverty such as Reconstruction and Development Programme (RDP) housing and a social welfare system aimed at empowering disadvantaged groups across South Africa through the disbursement of social grants to individuals in need (Khosa \& Kaseke, 2017). Post-apartheid programmes were intended to reduce inequality and alleviate the social-economic impact of poverty. One of the programmes, social welfare, catered for those groups disadvantaged by increasing unemployment in the country (Bonti-Ankomah, 2011).

As the employment rate has increased so have the prices of food, while the average household income remains insufficient to provide for basic needs (average household income in South Africa is R2,500 per month - about US $\$ 170$ or $£ 123$ ). Therefore, social welfare now offers the foster care grant for children separated from their biological parent(s) due to abuse, neglect or death (Rogan \& Reynolds, 2019). Foster parents receive the grant to enable them to care for foster children. South Africa's current system of social assistance is intended to support the well-being of vulnerable children and their families (Hearle \& Ruwanpura, 2009). However, the extent of poverty and unemployment undermine the benefits of the existing grants. Most families use the grants for general household essentials, as the grant is the only source of income (Hall \& Proudlock, 2011). The research questions that guided the study were:

1. How effective is foster care grant in meeting the basic needs of beneficiaries?

2. For what supplies do foster parents mostly use the grant?

\section{Literature review}

This section of the article covers in-depth literature on the legal rights of foster children, the responsibilities of foster parents and the usefulness of the foster care grant.

\section{The rights of foster children}

The Constitution of the Republic of South Africa 108 of 1996 section 28 (3) defines a child as 'a person under the age of 18 years. A foster child is a child placed in alternative care and raised by somebody who is not his or her biological parent. 
The Children's Act No 38 of 2005 section 150(1) (a) to (i) states

To identify a child as someone in need of care and protection. The child should be under eighteen years of age, have been abandoned, abused, neglected or orphaned, deprived of any resources for upkeep, and begging for a living on the street.

Furthermore, the child can be dependent on illegal substances and without any support to acquire treatment for addiction, or have been exploited or exposed to abuse. Lastly, the child will be under physical or psychological threat if returned to the biological family.'

Foster children have equal rights with any other child in the country. Section 28 of the Constitution of South Africa 108 of 1996 focusses on human rights and provides a systematic outline of children's rights. This does not mean that other rights cherished in our constitution do not apply to them. The following paragraphs from section 28 of the Constitution protects children from being victimised and exploited. Every child has the right:

b) To family care or parental care, or to appropriate alternative care when removed from the family environment;

c) To basic nutrition, shelter, basic health care services and social services;

d) To be protected from maltreatment, neglect, abuse or degradation;

e) To be protected from exploitative labour practices;

f) Not to be required to perform work or provide services that,

i) Are inappropriate for a person of that child's age; or

ii) Place at risk the child's well-being, education, physical or mental health or spiritual, moral or social development.'

(The Constitution Of The Republic Of South Africa 108, 1996).

\section{Responsibilities of foster parents in providing for the need of beneficiaries}

The Children's Act 38 of 2005 section 188 (1) as cited in Nsthongwana \& Tanga (2018) stipulates that 'a foster parent of a child has those responsibilities and rights in respect of the child as set out in an order of a children's court, placing the child in the care of the respective foster parent'. The foster parent is responsible for providing a secure and stable home for the children in their care. However, Rhodes, Orme \& Mcsurdy (2013) argue that the absence of unanimity between social service professionals around the duties of foster parents has created role confusion amongst foster parents. According to Rhodes et al (2013), welfare organisation have not implemented uniform descriptions of foster parenting. Rhodes et al (2013) mention that rocedures for refining enlistment, training and preservation of foster homes and assuring quality care for children require the provision of clear guidelines to 
foster parents on their role and responsibilities.

Foster parents have a distinct and an important role that integrates family and agency responsibility. Foster parents fulfill roles, which are given to them by the welfare system and they assist children in dealing with issues such as separation, attachment and uncertainty (Rhodes et al, 2013). According to Ntshongwana \& Tanga (2018) in the process of caring for vulnerable children, foster parents determine the child's outcome and foster parents have a significant role in caringfor the children and nurturing them (Rogan \& Reynolds, 2019).

Ntshongwana \& Tanga (2018) stipulate that foster parents have substantial roles in providing care, support and supervision in aid of facilitating holistic development of children in their care:

the family should provide unwavering support and maintain family stability in order to facilitate the emotional, physical and spiritual growth of children. Furthermore, foster parents have a great contribution and impact in the provision of family-based care that they have complicated histories which sometimes lead to troubled and challenging behaviours.

\section{Usefulness of the child support grant}

Hall \& Woolard (2012) found that the disbursement of social grants in South Africa considerably reduces poverty particularly amongst low-income homes. Although it is a very small benefit, the 'foster care grant effectively buffered poor households against shocks, including the worst effects of the global recession of 2009/10' (Hall $\&$ Woolard, 2012). According to Neves, Samson, van Niekerk, Hlatshwayo \& du Toit (2009)

Social grants including the foster care grant create potential economic benefits, for instance, it increases beneficiaries' abilities to cope with potential risks and insecurities, and lessens recipients' exposure to shocks. The provision of social grants has generally resulted in positive outcomes concerning improving the lives of vulnerable and poor people'

Hall \& Proudlock (2011) found that the foster care grant has developmental effects for children, improving their access to nutrition, education and other basic human rights, and health care facilities. Patel (2012) mentions that the majority of foster care grant beneficiaries specified that they used the grant money to purchase foodstuff, pay school fees and purchase school uniforms. For many, the foster care grant is a vital source of income; Patel (2012) identifies areas such as the Northern Cape and Limpopo where, 'overall, the grant made up 40 percent of household income and closer to half of household income'. Barrientos, Møller, Saboia, Lloyd-Sherlock \& 
Mase (2013) highlight that the grant potentially endorses labour, as foster parents invest in education of their children, which ultimately increases the changes of foster children being employed, and economically stable after their placement is dissolved (Patel \& Hochfeld, 2011).

\section{The financial impact of the grant for foster caregivers}

In South Africa, the decisions, opportunities and resources available for caring for foster children are rooted in and deeply intertwined with systems of inequality that are experienced along the lines of race, gender and class. The apartheid regime's deliberate and systematic incursion into family life has meant that the contexts in which children are cared for and the ability of families to secure care are often circumscribed by variables beyond the control of the family (Hendricks $\&$ Tanga, 2019).

Foster care grant is payable to the primary caregivers of foster children for the benefit of those children(Khosa \& Kaseke, 2017). The aim of the foster care grant is to support these primary caregivers by making a contribution to supplementing their resources in order to enhance their capacity to provide adequately for the growth and development of children. This grant is an attempt to make some of the children's rights a reality. According to Delany, Ismail, Graham and Ramkissoon (2008), the foster care grant was meant to cater mainly for the primary requirements of children. Although the grant is targeted at children, some of the caregivers tend to misuse the grant, which then results in children living in poverty (Makhubu $\&$ Ndenze, 2013). Such poverty, is strongly associated with less schooling, lower educational attainment, malnutrition, and a low standard of living (Department of Social Development, South African Social Security Agency \& UNICEF, 2011). As a result of the prevalence of poverty in many communities there are instances where the grant is not spent specifically on children, but shared among other family members (Department of Social Development, South African Social Security Agency \& UNICEF, 2011). In the study conducted by Niehaus and Shapiro (2010) on the effects of cash transfers on low-income households in developing countries the authors found that in Western Zambia less than 0.5 percent of the transfers were misspent on alcohol and tobacco. It was also established that 1.8 percent of a cash transfer to Mexican households was spent on alcohol. In South Africa the Department of Social Development, South African Social Security Agency \& UNICEF (2011) reported that the grant is sometimes utilised to purchase alcohol, pay for visits to hairdressers by caregivers, spending on boyfriends, gambling, cell phones, clothes for caregivers and luxury foods. The study conducted by Surender, Ntshongwana, Noble and Wright (2007) also established that some of the caregivers spent the money on liquor or clothing for themselves. This is a clear indication that the grant is not always utilised in the best interest of children. 


\section{Methodology}

The study explored the views of foster parents on the sufficiency of the foster care grant in meeting the basic needs of beneficiaries. A qualitative research approach was employed. This enabled the researcher to gain in-depth information from participants on the phenomenon explored. Taylar, Bogdan and DeVault (2015:8) stipulate that qualitative research 'refers in the broadest sense in research that produces descriptive data on people's own written or spoken words and observable behaviour'.

\section{Research design}

An exploratory research design was adopted, using a qualitative method of data collection. When a qualitative approach is used, participants share their experiences and understanding without any judgement from the researcher. Researchers do not embrace any information that could change the meaning of anything expressed by a participant. A qualitative approach permits the researcher an opportunity to learn and understand diverse social and cultural contexts. Qualitative data takes the form of comprehensive explanations of situations, individuals, interactions, observed behaviours, procedures, attitudes, thoughts, beliefs and direct quotations from persons who have experienced or are experiencing the phenomenon under investigation. Qualitative data is typically presented in the form of texts, which could include interview transcripts or organisational documentation; though, it may also contain non-textual information or data in the form of tables, images, audio and audio-visual recordings (Denzin and Lincoln, 2012).

\section{Study area}

The study was conducted with foster parents in selected areas of Amathole District Municipality, Eastern Cape Province. There are 9 provinces in South Africa amongst which the Eastern Cape has the second highest percentage of foster care grant beneficiaries after Limpopo Province. The study used purposive sampling. The sample consisted of 25 foster parents from selected areas in Amathole District Municipality. The researcher chose these participants with the assistance of Department of Social Development because they lived in close vicinity to each other, their foster children attended the same schools and they were fluent in English, which was an advantage as most inhabitants of Amathole District speak IsiXhosa. These participants varied in age, ethnicity, education, employment status, marital status and experience in fostering children. 


\section{Instruments of data collection and method of data analysis}

For the purpose of this study, exploratory data was identified through in-depth interviews and presented in the form of thematic analysis. Thematic analysis is the process of identifying patterns or themes within qualitative data. Braun and Clarke (2006) suggest that it is the first qualitative method that should be learned as it provides core skills that will be useful for conducting many other kinds of analysis. Analysis was done by recording interviews, transcribing them verbatim, and then using these transcripts to identify themes. Descriptive coding that describes cases was mainly used in this study. This type of coding includes both coding of information in categories or themes and the use of attributes to clarify findings.

\section{Ethical considerations}

Punch (2013: 60) has emphasized the importance of ethical considerations, 'researchers have two basic categories of ethical responsibility: responsibility to those, both human and nonhuman, who participate in a project; and responsibility to the discipline of science to be accurate and honest in the reporting of their research.' The participants selected to participate in the study did so voluntarily there was no form of coercion. The participants were assured of no harm as they were informed that they are not obliged to answer questions that make them uncomfortable and also that they could leave at any time when they feel uncomfortable.

\section{Findings And Discussion}

This section elucidates themes and sub-themes derived from the study findings. To protect confidentiality the participants are identified by number. $\mathrm{FP}=$ foster parent).

\section{Theme 1: The effectiveness of the foster care grant in meeting the basic needs of beneficiaries}

\section{Sub-theme 1.1: Nutrition}

In his hierarchy of need. the American psychologist Abraham Maslow states that food is one of seven basic needs, available to the human species to provide nutrition and promote nourishment and growth. All 25 foster parents agreed that food is the basic need of the foster children; hence, a large amount of money is spent on buying food. 
FP 12 stated 'I spend one thousand rand on food and there are other things like rent that I have to pay.'

FP 22 said 'I spend more money on groceries especially during school holidays because children are around all day during that period'

FP 15 mentioned 'I buy groceries like flour, sugar and maize every month. During school holidays if the children performed well as per indication in their report cards I spoil them with sweet treats every day.'

Hendricks \& Tanga (2019) found that studies of fostered children indicate nutrition disadvantage among fostered children as a health risk. This was due to unequal treatment by the foster parents. However, in recent years, social workers are more active in monitoring the nutrition intake of foster children and sanctioning parents who fail to provide proper nutrition (Nsthongwana \& Tanga, 2019).

\section{Sub-theme 1.2: Academic Needs}

According to (Ayasse, 2005) foster children often experience a variety of social and emotional problems that stem from maltreatment in foster homes. These problems have a negative influence on their ability to progress in school. From the findings of this study, all 25 foster parents agreed that education is important to all children, as it will enable them a successful life in the future.

FP 3 stated 'I pay for the child's transport to school, buy school uniform each year and buy stationery'

FP 5 reported 'I replaced the child's school uniform every year and buy stationery when it is needed'

FP 3 mentioned 'I give my child lunch money everyday day even though there is a feeding scheme at school I know that children often get hungry and cannot function of an empty stomach'

Twenty foster parents mentioned academic needs of children such as school uniform, stationery and school transport as among the basic needs on which the money should be spent. Two of the foster parents did not say anything about children's academic needs.

\section{Sub-theme 1.3: Recreational Activities}

Recreational activities are activities performed by students that fall outside the formal school curriculum. Hendricks \& Tanga (2019) noted that student participating in recreational activities increases socialisation within the academic settings, the family 
and social setting. However, recreational activities are important for the development of social skills in children.

FP 24 stated 'I do pay for the child's school trips because I think it is good for them to go and learn outside the classroom'

FP 16 stated 'It is important to pay for their sport trips so that they do not feel left out'

On many occasions, families that have their foster children involved in recreational activities find that it is beneficial to the children. Hendricks \& Tanga (2019) argue that the participation of children in after-school activities does not always lead to successful results, some children suffer consequences such as failure, lack of concentration and fatigue. Ntshongwana \& Tanga (2018) agree that however, majority of parents across the globe view recreational activities as a good way to keep children out of trouble.

\section{Theme 2: The identification of necessities for which foster parents uses the grant}

\section{Sub-theme 2.1: Academic Investment}

Every foster parent should consider the future of the child and invest in their academic life, that is, saving money so that the child may be able to further his or her studies. Academic investment is defined as

an investment or saving for your child's education using unit trusts gives you control over your investment: you decide how to invest, when to access the money and what to do with it, based on which years of education you are planning for. (Cichello, 2015)

FP 2 said, 'I do invest one hundred and fifty monthly as I was told by the magistrate and social worker during the placement and review process and I don't usually skip month as it is debited by the bank'.

FP 3 stated that, 'I save one hundred rand monthly but when a child need money for school purpose I with draw some money and continue with savings'

FP4 stated that, 'I don't save every month there are months where the money is insufficient so I don't save but I make sure I don't skip more than two months or I save the following month'.

When it comes to academic investment for foster children, most children fostered by close relatives are motivated to advance their education these foster children are 
often supported (financially and emotionally) similarly to thr biological children of the foster parents (Hall \& Proudlock, 2011). On the other hand, children who are fostered by strangers are not encouraged to enroll in college or universities after completing their secondary schooling. Little attention is paid to support foster care parents, especially elderly kin who may often be the sole caregiver of foster children and whose abilities are constrained by maternal privation (Hearle \& Ruwanpura, 2009). The majority of foster care parents are unemployed and depend on the small foster child grant that they receive from the state to provide for their families. The termination of the foster child grant plunges young adults and families back into the cycle of dire poverty and puts them at risk of not maintaining a sustainable livelihood. Social development provides the mandate to the Department of Social Development to respond to, among other things, the socio-economic needs of all South Africans, especially people who were previously disadvantaged, and the poor (Hölscher, 2008).

\section{Sub-theme 2.2: Sartorial}

Sartorial refers to clothing that falls in the basic needs of a child. The wearing of clothes is mostly restricted to human beings and is a feature of all human societies and it serves many purposes.

FP 4 mentioned; 'that she does not afford to buy new clothes for each season for her foster child because the grant is not sufficient it ends before even buying electricity for the month so she waits for her daughter who works in one of the retail shops in Cape Town to send clothes for everyone in the house.'

FP 25 said: 'she depends on laybys which she makes twice a year, for summer and winter which makes it much better for her to get a relief.'

Parents understand that each and every child deserves to have new clothes in both seasons of the year which is summer and winter but at times it is difficult to maintain that due to the inadequate funds of foster care grant to spend on clothes but they do try by all means to make those clothes available (Hall \& Woolard, 2012).

\section{Sub-theme 2.3: Funeral Insurance}

According to ( Neinaber \& Preiss, 2006:5) funeral insurance is described as 'an undertaking by one party, the insurer to another policyholder to provide in consideration of predetermined contribution usually payable at predetermined regular interval, a funeral service or cash back or combination of both on the death of the life assured in respect of whom the policyholder has an insurable interest'. Regardless of the aggregate of contributions, the insurer may have received in respect thereof at the time of the death of the life assured. All participants agreed that this 
is a necessity for all South Africans not only foster parents.

FP 3 mentioned that 'although at times funeral policy will not deduct its money on the exact date of the pay day, but she makes sure that she does not take that money because she does not want the policy to lapse.'

FP 5 said 'at times the policy would not deduct its money from the foster care grant and she would feel happy and go and withdraw the money to patch other depts., but when another payment comes the policy will make double transactions and still will leave another gap and now she has realised that its taking her backwards.'

FP 2 states that: 'she feels relieved every time when the policy deducts its money and she wishes that her funeral policy could be the first to deduct its money.'

Based on the study conducted, all nine foster parents stated that they do have policies, which help during the times of death, but the policy caters for everybody who stays in the household.

\section{Conclusions}

Foster care parents attempt to provide for the basic needs of children in majority of cases the grant is just enough to cover the basic needs of beneficiaries. Foster parents were of the view that the grant could be increased to provide funds for some additional stuffs like educational policies, which is essential in securing a decent future for children.

Like any other parent, foster parents want their children to have a better future and continue their tertiary education. Each parent should be obliged to invest for the future of foster children. Beneficiaries of foster care grant should all be afforded the opportunity to participate in recreational activities to build their social skills and some may even pursue sport as a career. Through associating with other children in recreational activities it assists children in establishing a confident personality and learn what they like and what they do not like. 


\section{Recommendations}

Social workers need to frequently monitor the academic investment and advice foster parents to invest affordable amount

1. Foster parent need to encourage children to participate in recreational activities especially sport as it assist children's development

2. Parents who are saving or investing to accounts that are accessible should consider having investment where they will not be able to withdraw money until the child has reached a certain age like eighteen or twenty-one years.

\section{References}

Ayasse, R.H. (2005) Children and schools: Addressing the needs of foster children, the foster youth services program Children \& Schools, 17, 4, 207-216

Bonti-Ankomah, S. (2011) Addressing food insecurity in South Africa. In SARPN conference on land reform and poverty alleviation in Southern Africa. Pretoria (pp. 4-5)

Barrientos, A., Møller, V., Saboia, J., Lloyd-Sherlock, P., \& Mase, J. (2013) Growing'social protection in developing countries: lessons from Brazil and South Africa. Development Southern Africa, 30, 1, 54-68

Braun, V., \& Clarke, V. (2006) Using thematic analysis in psychology. Qualitative research in psychology, 3, 2, 77-101

Cichello, S. A. (2015) Oxygen absorbers in food preservation: A review. Journal of food science and technology, 52, 4, 1889-1895

CHILDREN'S ACT 38 OF 2005. Published in the Government Gazette (28944) Pretoria: Government Printer

CONSTITUTION OF THE REPUBLIC OF SOUTH AFRICA. (1996) Pretoria: Government Printer.

Delany, A. Ismail, Z. Graham, 1. \& Ramkissoon, Y. (2008) Review of the Child Support Grant: uses, implementation and obstacles. Johannesburg: Community Agency for Social Enquiry.

Denzin, N. K., \& Lincoln, Y. S. (2012) Manual de investigación cualitativa (Vol. 1) Barcelona: Gedisa

DEPARTMENT OF SOCIAL DEVELOPMENT, SOUTH AFRICAN SOCIAL SECURITY AGENCY \& UNICEF. (2011) Child Support Grant Evaluation2010: Qualitative Research Report. Pretoria: UNICEF

Hall. K \& Proudlock, P. (2011) Orphaning and the Foster Child Grant: A return to the 'care or cash' debate. Children Count Brief. Cape Town: University of Cape Town, Children's Institute Hall, K., \& Woolard, I. (2012) Children and inequality: An introduction and overview. Cape Town: University of Cape Town, Children's Institute

Neves, D., Samson, M., van Niekerk, I., Hlatshwayo, S., \& Du Toit, A. (2009) The use and 
effectiveness of social grants in South Africa.Cape Town: University of Cape Town, Children's Instituten

Hearle, C. \& Ruwanpura, K.N. (2009) Contentious care: foster care grants and the caregiverorphan relationship in KwaZulu-Natal Province, South Africa. Oxford Development Studies, $37,4,423-437$

Hendricks, E. A., \& Tanga, P. T. (2019) Effectiveness of child protection services rendered to children in need of care and protection: A study of Childline South Africa. Ubuntu: Journal of Conflict and Social Transformation, 8, 2, 31-52

Hölscher, D. (2008) The Emperor's new clothes: South Africa's attempted transition to developmental social welfare and social work. International Journal of Social Welfare, 17, 2, 114-123

Khosa, P., \& Kaseke, E. (2017) The utilisation of the child support grant by caregivers: the case of Ba-Phalaborwa municipality in Limpopo Province. Social work, 53, 3, 356-367

Makhubu, N. \&Ndenze, B. (2013) Young moms abuse grant system. IOL News, 2nd September

Niehaus, P. \& Shapiro, J. (2010) Effects of cash transfers on low-income households in developing countries: a review of the evidence. Technical Report, Nairobi, Kenya

Nienaber, P. M., \& Preiss, J. (2006) Funeral Insurance: A Perception from the Office of Ombudsman for Long-term Insurance. S. Afr. Mercantile LJ, 18, 291

Ntshongwana, Z., \& Tanga, P. (2018) Exploring the experiences of biological children living with foster children. Southern African Journal of Social Work and Social Development, 30, 2, 1-14

Patel, L. (2012) Poverty, gender and social protection: Child support grants in Soweto, South Africa. Journal of Policy Practice, 11, 1-2, 106-120

Patel, L., \& Hochfeld, T. (2011) It buys food but does it change gender relations? Child Support Grants in Soweto, South Africa. Gender \& Development, 19, 2, 229-240

Punch, K. F. (2013) Introduction to social research: Quantitative and qualitative approaches. London: Sage

Rogan, M., \& Reynolds, J. (2019) Trends in the working poverty rate (WPR) in post-apartheid South Africa, 1997-2012. Development Southern Africa, 36, 5, 699-715

Rhodes, K. W., Orme, J. G., \& McSurdy, M. (2013) Foster parent's role performance responsibilities: Perceptions of foster mothers, fathers, and workers. Children and Youth Services Review, 25, 12, 935-964

Surender, R., Ntshongwana, P., Noble, M. \& Wright, G. (2007) Employment and social security: A qualitative study of attitudes towards the labour market and social grants. Pretoria: Department of Social Development.

Taylor, S. J., Bogdan, R., \& DeVault, M. (2015) Introduction to Qualitative Research Methods: A guidebook and resource. Chichester: John Wiley 